\title{
РЕАЛІЗАЦІЯ ПОТЕНЦІАЛУ ПРОДУКТИВНОСТІ РІЗНИХ ЗА ПОХОДЖЕННЯМ СОРТІВ МАЛИНИ В УМОВАХ ПІВНІЧНО-СХІДНОГО ЛІСОСТЕПУ УКРАЇНИ
}

\author{
Горбась С. М., Бакуменко О. М.
}

\section{ВСТУП}

Малина - швидкоплідна і високоврожайна культура. Вирощуючи іiі на високому агротехнічному фоні 3 урахуванням всіх властивостей загалом і кожного сорту зокрема, вже на другий рік після садіння можна отримати перший урожай дієтичних плодів приблизно 2025 т/га, а на третій-п’ятий рік - 60-80 ц/га. Але дуже важливо знати, як правильно вирощувати та доглядати кущі малини в саду.

Здавна малину цінують за смакові, харчові й лікувальні властивості. В їі плодах залежно від сорту й умов вирощування містяться цукри (до 10\%), органічні кислоти, солі фосфору, заліза, кальцію, магнію, пектин, дубильні речовини, вітаміни С (30-60 мг\%), В1, В2, D, Е, Р-активні речовини, ефірні олії, антибіотики, $0,6-0,9 \%$ пектину $1,2-2,3 \%$ органічних кислот. Серед останніх особливе місце займає саліцилова кислота, чим зумовлене використання ягід для зниження температури під час застудних захворювань ${ }^{1}$. У плодах малини міститься також фолієва кислота (вітамін В 9), яка підсилює кровотворення, запобігає недокрів'ю та лейкемії. 3 інших плодів він міститься лише у вишні і винограді ${ }^{2}$. Серед інших ягідних культур малина виділяється високим вмістом заліза, а також іншого гематогенного елементу - міді (у 2-3 рази більше, ніж усмородині). Поєднання гематогенних елементів (залізо й мідь) 3 фолієвою кислотою визначає високу корисність малини ${ }^{3}$.

На початок 2019 року загальна площа ягідних насаджень в Українських господарствах усіх категорій становить 21,2 тис. га. Зазначається, що найбільша частка за площами ягідних насаджень припадає на суницю садову - 8,2 тис. га. На другому місці - смородина чорна і червона (порічка) - 5 тис. га. Третє місце за площею насаджень посідає малина 4,9 тис. га. Проте рівень промислового виробництва плодів цієї культури в Україні недостатній для повного забезпечення населення високотоварною конкурентоздатною продукцією, оскільки частка сільськогосподарських підприємств становить лише близько $8 \%$ у загальному обсязі. Пріоритетними у вирощуванні цієї культури в Україні $є$ Вінницька,

\footnotetext{
${ }^{1}$ Рожко Н.Д. Ягоды и их лечебные свойства. Здоров'я. 1966. С. 38-40.

${ }^{2}$ Ильина С. Двенадцать месяцев здоровья. Энциклопедия народной медицины, т. II. Київ : Логос, 1998. С. 31-33.

Ильина С. Двенадцать месяцев здоровья. Энциклопедия народной медицины, т. II. Київ : Логос, 1998. С. 31-33.
} 
Київська, Черкаська, Кіровоградська області та регіони з розвиненою переробною промисловістю. Основною причиною такого становища і в більшості країн світу вважають екстремальний вплив кліматичних умов на рослини, що спостерігається останнім часом.

Свіжі ягоди малини можна мати на столі впродовж усього року, вирощуючи рослини суперранніх, середніх, пізніх і ремонтантних сортів, а заморожуючи ягоди на зиму, вдається зберегти не лише їх колір, смак та аромат, а й біохімічний склад. Непогано зберігаються їхні властивості у продуктах переробки, для приготування яких зазвичай використовують основну масу врожаю.

На цей час у світі створено близько 600 сортів малини. 3 появою нових сортів постає необхідність виявлення серед них адаптованих до певних умов вирощування, які володіють комплексом господарсько цінних ознак. Залучення їx до створення промислових плантацій забезпечить максимальну прибутковість виробництва ${ }^{4}$.

У сучасних соціально-економічних умовах одним із найважливіших завдань є збільшення і стабілізація виробництва ягід малини в Україні. На цей час у Державному реєстрі немає сортів малини, які б повністю відповідали грунтовим і кліматичним умовам північно-східного Лісостепу України .

Зважаючи на вищесказане, добір сортів малини 3 комплексом господарсько цінних ознак, високо адаптованих до стрес-факторів довкілля, $є$ своєчасним та актуальним. Тому розв'язання проблеми добору кращих сортів цієї зони вирощування $\epsilon$ актуальним завданням в ягідництві.

Аналіз основних досліджень і публікацій. Успішне вирощування будь-якої культури в конкретному кліматичному регіоні залежить від декількох факторів, але перш за все адаптивності рослини до умов навколишнього середовища. Однією з найбільш цінних ягідних культур $\epsilon$ малина, плоди якої володіють унікальними поживними та лікарськими властивостями ${ }^{6}$. Зусиллями Українських селекціонерів створено близько 10 перших вітчизняних сортів малини ремонтантного типу, 3 яких 5 включені в Держреєстр України та допущені до використання, інші проходять державне і виробниче випробування.

Сорт - фактор пом'якшення впливу екстремальних умов погоди. Вимоги до сорту як одного із факторів стабільного підвищення врожайності зростають. При цьому сорт як біологічну систему не можна замінити нічим - він унікальний. Тому у підвищенні врожайності малини важлива роль належить підбору адаптивних до конкретних умов

4 Касіянчук В.Д., Ковач М.М., Касіянчук М.В. Перспективи використання дикоростучих плодів, ягід і грибів в умовах Прикарпаття для виготовлення продукції лікувально-профілактичного призначення. Науковий вісник наиіонального лісотехнічного університету України. 2013. Вип. 23.7. С. 152-155.

Барабаш О.Ю., Леонтьєв О.М., Гонтар В.Т. Овочівництво і плодівництво : підручник. Київ : Вища школа, 2000. 503с.

Жуковский П.М. Культурные растения и их сородичи. Ленинград, 1971. 752 с. 
вирощування сортів 3 відповідним генотипом ${ }^{7}$. Встановлено, що вирощування високопродуктивних сортів малини з урахуванням їх адаптивних властивостей за умов відповідного рівня культури зонального землеробства дає змогу підвищити врожайність на $11-50 \%{ }^{8}$.

Особливістю малини $є$ наявність великої кількості адвентивних бруньок i етильованих пагонів на додаткових коренях. Бруньки формуються здебільшого в середині літа. Вони мають вигляд горбочків, які до осені проростають на 5-8 см у грунті. Навесні з них проростають кореневі паростки 3 власними кореневищем і коренями. Ці паростки втрачають зв'язок з материнською рослиною, після чого являють собою самостійні однорічні рослини 9 .

Ремонтантна малина порівняно з малиною звичайною має й інші переваги: вона більш стійка до хвороб і шкідників, тому червиві ягоди трапляються рідко; за нею набагато простіше доглядати; майже всі ремонтантні сорти великоплідні. У сучасному саду кущі ремонтантної малини стали таким самим звичним явищем, як чорна смородина, агрус, порічки, полуниця та інші повсюдно вирощувані ягідні культури.

У житті рослин малини важливу роль відіграють екологічні фактори, до яких належать світло, тепло, вода, грунт тощо. Однак вимоги різних сортів до зовнішніх умов середовища неоднакові. Тому врахування комплексу екологічних чинників під час вибору сорту та технології вирощування культури $\epsilon$ необхідною умовою одержання високого врожаю.

Малина є цінним медоносом. 3 гектара насаджень бджоли можуть зібрати до 116 кг меду. Продукти малини використовують у кондитерській промисловості, вони $€$ цінним матеріалом для виготовлення різноманітних напоїв і бальзамів.

Окреме значення посідають сорти ремонтантної малини, промислові насадження якої в світі і в Україні постійно збільшуються. Причина цього - скороплідність культури (промисловий урожай отримують вже наступного після садіння року), відносна нескладність технології вирощування, менша уражуваність хворобами та пошкоджуваність шкідниками. Між тим урожайність сортів ремонтантної малини не поступається перед літніми ${ }^{10}$.

Станом на 2019 рік у «Державного реєстру сортів рослин, придатних для поширення в Україні» зареєстровано 31 сорт малини ${ }^{11}$.

У зв'язку з таким різноманіттям підприємствам, що спеціалізуються на вирощуванні малини, важко визначитися із сортом, тому дуже

${ }^{7}$ Витковский Л.В. Плодовые растения мира. Санкт-Петербург : «Лань», 2003. C. 364-368.

${ }_{9}^{8}$ Жуковский П.М. Культурные растения и их сородичи. Л., 1971. 752 с.

9 Витковский Л.В. Плодовые растения мира. Санкт-Петербург : «Лань», 2003. C. 364-368.

10 Марковський В.С., Бахмат М.І. Ягідні культури в Україні. Кам’янецьПодільський : ПП «Медозбори-2006», 2008. 200 с.

11 Державний реєстр сортів рослин, придатних до поширення в Україні в 2019 році / Держ. ветер. та фітосанітарна служба України. Київ : Алефа, 2019. 497 с. 
важливо звертати увагу на сорти, які найбільш адаптовані до природнокліматичних умов зони вирощування. У багатьох підприємствах саме невідповідність сорту природно-кліматичним умовам $\epsilon$ причиною недобору врожаю. Щоб уникнути таких негараздів, слід ознайомитися 3 реакцією сорту на умови вирощування ${ }^{12}$.

Для вирішення таких нагальних питань у лабораторії садівництва та виноградарства Сумського НАУ закладена ділянка сортів малини різних селекційних установ, з метою виявлення в них сортів, які здатні найбільш повно реалізувати свій генетичний потенціал в умовах Північно-східного Лісостепу України.

Мета досліджень - проаналізувати продуктивність сортів малини та визначення ступеня їх адаптивності за вирощування в умовах Північносхідного Лісостепу України, що дозволить виявити найбільш адаптовані сорти до умов цієї зони вирощування.

\section{1. Вихідний матеріал, методика та умови проведення досліджень}

Експериментальні дослідження проводились упродовж 20172019 рр. на базі лабораторії садівництва та виноградарства Сумського національного аграрного університету (СНАУ) Міністерства освіти і науки України. СНАУ територіально розташований на околиці міста Суми, що входить до північно-східної частини лівобережного Лісостепу України. Географічні координати - північна широта $50^{\circ} 54^{\prime} 43^{\prime \prime}$, східна довгота $34^{\circ} 48^{\prime} 12^{\prime \prime}$. Місто розташоване на берегах річки Псел при впаданні в неї річки Сумки. Суми охоплює частина Середньоросійської височини і Придніпровської низовини (близько 138 м над рівнем моря). Найвища точка області - 246,2 м над рівнем моря. Північна частина області лежить у межах Новгород-Сіверського Полісся, південна - належить до лісостепової зони.

Грунти дослідної ділянки СНАУ - чорнозем типовий глибокий малогумусний, середньосуглинковий, 3 високою та середньою забезпеченістю елементами мінерального живлення. Уміст гумусу коливається близько $3,9 \%$. Реакція грунтового розчину близька до нейтральної (5,8). Легкодоступного азоту - 87 мг, фосфору - 109 мг і обмінного калію - 100 мг на 1 кг грунту. Загалом можна стверджувати, що грунтові умови дослідного поля СНАУ є типовими для зони, що дозволяє реалізовувати генетично зумовлений потенціал продуктивності сортів малини.

Землі, де виконувалися дослідження, віднесені до другого агрокліматичного району Сумської області, який за багаторічними даними характеризується помірним, континентальним кліматом 3 теплим літом і не дуже холодною зимою 3 відлигами. На території області відсутні великі водні басейни, які б впливали на клімат загалом чи на його окремі елементи.

12 Барабаш О.Ю., Леонтьєв О.М., Гонтар В.Т. Овочівництво і плодівництво : підручник. Київ : Вища школа, 2000. 503с. 
Аналіз погодних умов 2017-2019 років досліджень проведений на основі щорічних даних, що надавались метеостанцією Інституту сільського господарства Північного Сходу НААН, розташованою у п'яти кілометрах від дослідного поля СНАУ. Землі СНАУ віднесені до другого агрокліматичного району Сумської області, який за багаторічними даними характеризується помірним, континентальним кліматом з теплим літом $\mathrm{i}$ не дуже холодною зимою з відлигами. На території області відсутні великі водні басейни, які б впливали на клімат загалом чи на його окремі елементи. За середніми багаторічними даними найбільш холодними місяцями $€$ січень і лютий, а теплими - липень і серпень. Абсолютний мінімум температур повітря найчастіше за роками має місце в січні, а максимум - у серпні. Середньодобова (середньорічна) температура повітря впродовж 2017-2019 рр. коливалась від +7,9 до $+9,6{ }^{\circ} \mathrm{C}$, а тривалість безморозного періоду близька до 230 днів. За середнім багаторічним показником випадає у межах 597-600 мм опадів, причому більша частина - у теплий період (квітень-жовтень).

Об'єктом дослідження слугували 8 сортів малини, в тому числі 4 традиційних - Новокитаївська (сорт-контроль), Персея, Промінь, Саня i 4 ремонтантних - Бабине літо (сорт-контроль), Зєва, Космічна, Бруквяна. Рослини малини в кількості по 20 рослин були висаджені в травні 2016 p. на ділянці площею 0,15 га рядами по сортам. Технологія вирощування малини була загальноприйнятою для цієї зони ${ }^{13,14}$.

Коротка характеристика досліджуваних сортів:

Новокитаївська. Ранньостиглий сорт української селекції (Інститут садівництва УААН). Отриманий у 1945 році шляхом схрещування сортів Китаївська i Новость Кузьміна. Кущ середньорослий, прямостоячий, пагони 3 невеликою кількістю колючок. Ягоди однорідні, середньою масою 2,2-2,9 г, світло-малинового кольору, округло-конічної форми. Урожай дозріває дружно, ягоди придатні для переробки та реалізації у свіжому вигляді. Транспортабельність хороша. Сорт має середню стійкість до хвороб пагонів та кореневої гнилі. Зимостійкість висока.

Персея. Ягоди великі та середні (3,1-5 Сорт раннього строку достигання. Походження: гібридна форма 16-324 х гібридна форма 4-4. Автор: О.П. Лушпіган. До Державного реєстру сортів рослин внесений у 2007 році. Рекомендований для вирощування в зонах Лісостепу та Полісся. Стійкий до грибних хвороб. Зимо- та посухостійкий. Кущ високий, пряморослий, 3 пониклою верхівкою. Пагоноутворювальна здатність середня. Урожайність - 22 т/га. Плоди одномірні, конічної форми, темно-червоні, блискучі, добре відокремлюються від плодоложа, приємного кисло-солодкого смаку (8,1 бала). Достигають дружно. Знімальна стиглість настає у другій декаді червня.

13 Шестопаль О.М. Типові технологічні карти на створення насаджень горіхоплідних та ягідних культур. Київ, 2006. 90 с.

${ }_{14}$ Ратомська 3.С. Механізація рільництва і садівництва : підручник. Київ : Видавництво «А.С.К.», 2006. 
Використання універсальне. У плодах міститься, \%: сухих розчинних речовин - 12,2, цукрів $-6,2$, кислот $-2,1$, а також, мг/100 г сирої маси: вітаміну C -20 , фенольних сполук -235 .

Бабине літо. Ремонтантна малина. Була виведена при схрещуванні американського ремонтантного генотипу Вереснева з гібридом № 12-77 (Новина Кузьміна). Дозрівають ягоди в кінці червня, друга хвиля починається з середини серпня і триває до заморозків. Формування плодових зав'язей у сорту відбувається в основному на пагонаходнолітки. Ягоди розміщуються по всій довжині бічних відгалужень, кожне суцвіття утворює 150-300 плодів. Ягоди вагою 2,1-3,0 г мають форму усіченого конуса. М'якоть червоного кольору, соковита. Дегустаційна оцінка 4,5 бала. Вміст вітаміну С - 30 мг на 100 г плодів. Сорт стійкий до сірої гнилі та кучерявості, але сприйнятливий до збудників борошнистої роси і пурпуру плямистості. Рослини можуть піддаватися нападів павутинного кліща.

Промінь. Заявник - Національний аграрний університет. Молодих пагонів багато. Плодоносні пагони середньої довжини. Плід помірночервоний, великий, середньотвердий, помірно-глянсуватий. Період основного плодоношення на пагонах минулого року - влітку. Час достигання ягід пізній. Тривалість урожайного сезону на пагонах минулого року середня. Урожайність товарна - 7,9 т/га, урожай 3 куща - 0,2 кг, гарантована прибавка - 2,0 т/га, маса плоду - 3,7 г. Дегустаційна оцінка 9 балів, стійкість проти ураження хворобами - 9 балів.

Саня. Заявник - Інститут садівництва УААН. Рослина утворює середню кількість молодих пагонів. Плодоносні пагони середньої довжини. Плід помірно-червоний, великий, довший, ніж ширший, середньотвердий, помірно-глянсуватий. Період основного плодоношення на пагонах минулого року -влітку. Час достигання ранній. Тривалість урожайного сезону коротка. Середня врожайність 196,1 ц/га, середня маса ягоди - 3,8 г, максимальна - 4,6 г. Ступінь підмерзання бруньок - 1 бал. Ураженість хворобами: пурпуровою плямистістю - 1 бал, антракнозом - 1,5 бала. Пошкодження шкідниками: малиновим довгоносиком - 0,5 бала, попелицею - 1 бал. Вміст загального цукру $-5,28 \%$, вітаміну С $-26,15$ мг. Дегустаційна оцінка свіжих ягід - 8-9 балів. Транспортабельність -8 балів.

Зєва. Ремонтантний сорт малини швейцарської селекції. Дає урожай двічі за сезон. Пагони прямостоячі, товсті, помірно покриті шипами, що не гілкуються. Ягоди солодкі, щільні і ніжні, ароматні, округло-конічні, темно-червоного забарвлення, глянсові, масою 3-4 г, максимальна 5 г, транспортабельні. Початок дозрівання осіннього врожаю - друга половина серпня. Сорт плодоносить до самого настання заморозків. Призначення сорту універсальне.

Космічна. Заявник - Національний аграрний університет. Рослина утворює середню кількість молодих пагонів без шипів. Плодоносні пагони середньої довжини. Плід помірно-червоний, великий, довший, ніж ширший, твердий, помірно-глянсуватий. Період основного 
плодоношення на пагонах поточного року - восени. Час появи пагонів ранній. Тривалість урожайного сезону довга. Середня врожайність 82,0 ц/га (осіннє збирання), середня маса ягоди - 3,4 г, максимальна 8,3 г. Ступінь підмерзання бруньок - 2 бали. Ураженість хворобами: пурпуровою плямистістю й антракнозом - 1 бал. Шкідниками не пошкоджується. Вміст загального цукру - 6,4\%, вітаміну C - 55,0 мг. Дегустаційна оцінка свіжих ягід - 8-9 балів. Транспортабельність 8 балів. Сорт - ремонтантний.

Брусвяна. Приносить два врожаї за рік. Перші плоди з середини червня, а наступного разу починають збирати врожай 3 серпня i до глибокої осені. Плоди гарні на вигляд, мають типовий для малини кисло-солодкий смак, але у цього виду він більш насичений. Відмінною рисою сорту є велика щільність ягід, завдяки якій вони зберігають свою структуру, через що багато хто любить робити з неї варення. Садівники відзначають врожайність в 4-5 кг 3 куща, що також значно нижче значення 7-8 кг, зустрічається в рекламних матеріалах.

Польові роботи виконували відповідно до технологічних карт ${ }^{15}$. Основні обліки та спостереження проводили за «Програмою и методикою сортовивчення плодових, ягідних и горіхоплідних культур» ${ }^{16}$.

\section{2. Потенціал різних за походженням сортів малини в умовах Північно-східного Лісостепу України}

У сучасних умовах 3 недостатнім фінансуванням сільського господарства головним і найбільш доступним кожному господарству резервом збільшення врожайності малини $\epsilon$ впровадження високопродуктивних районованих сортів, яке без додаткових капіталовкладень підвищить на 20-30\% продуктивність культури.

Для впровадження в сільськогосподарське виробництво на 2019 рік в каталог сортів рослин, придатних для поширення в Україні, введено 35 сортів малини, 3 них 6 - ремонтантних ${ }^{17}$. Є думка, що ремонтантні сорти забезпечують отримання високих врожаїв, задовольняють вимоги споживачів за постійної наявності ягід та полегшують боротьбу 3 хворобами і шкідниками, зменшують ймовірність пошкодження рослин взимку в результаті щорічного зрізання стебел, що вже відплодоносили. Ця технологія доцільна в разі вирощування ремонтантних сортів малини, в яких урожай формується на пагонах поточного року.

Для аналізу та оцінки ремонтантних сортів в умовах Сумського НАУ було відібрано генотипи малини, створені установами різних

15 Шестопаль О.М. Типові технологічні карти на створення насаджень горіхоплідних та ягідних культур. Київ, 2006. 90 с.

${ }^{16}$ Седов Е.Н., Огольцова Т.П. Программа и методика сортоизучения плодовых, ягодных и орехоплодных культур. Орел: Изд-во Всеросийского научноисследовательского института селекции плодовых культур, 1999. 608 с.

17 Державна служба статистики України. URL: http://www.ukrstat.gov.ua. 
країн, 3 числа сортів, занесених у різні роки до Державного реєстру сортів рослин, придатних для поширення в Україні. Дані Державної служби статистики України в 2018 році вказують на значний зріст урожайності плодових та ягідних культур до 128,4 ц/га ${ }^{18}$. Проте необхідно відмітити, що погодні умови років досліджень та період плодоношення також мають впливати на урожайність досліджуваних генотипів. У середньому по досліджуваним сортам урожайність складала 58,5 цга.

Проаналізувавши традиційні сорти малини в 2017-2019 році, виявили, що істотна різниця між урожайністю досліджуваних зразків відсутня $-\mathrm{F}_{\text {фактичне }}=1,06>\mathrm{F}_{\text {критичне }}=4,06$ (табл. 1).

Таблиця 1

\section{Характеристика традиційних сортів малини} за врожайністю, 2017-2019 pp.

\begin{tabular}{|c|c|c|c|c|c|c|c|c|c|c|}
\hline \multirow{3}{*}{ Сорти } & \multicolumn{6}{|c|}{ Статистичні показники за роками } & \multicolumn{4}{|c|}{ За три роки, ц/га } \\
\hline & \multicolumn{2}{|c|}{2017 p. } & \multicolumn{2}{|c|}{2018 p. } & \multicolumn{2}{|c|}{2019 p. } & \multirow[b]{2}{*}{$\bar{x}$} & \multicolumn{2}{|c|}{$\begin{array}{l}\text { Область } \\
\text { похибки } \\
\end{array}$} & \multirow[b]{2}{*}{$\mathrm{R}$} \\
\hline & $\begin{array}{l}\bar{x}_{ \pm} \\
\overline{\bar{x}} \\
\mathrm{~S}^{x}, \\
\text { ц/га }\end{array}$ & $\begin{array}{l}\mathrm{V} \\
\%\end{array}$ & $\begin{array}{c}\bar{x}_{ \pm} \\
\overline{\mathrm{S}} \bar{x} \\
\text { ц/га }\end{array}$ & $\mathrm{V}, \%$ & $\begin{array}{c}\bar{x}_{ \pm} \\
\mathrm{S}^{\bar{x}}, \\
\mathrm{ц} / \text { га } \\
\end{array}$ & $\mathrm{V}, \%$ & & $\min$ & $\max$ & \\
\hline $\begin{array}{c}\text { Новокитаївська } \\
(\mathrm{St})\end{array}$ & $\begin{array}{c}48,3 \pm \\
0,40\end{array}$ & 1,45 & $\begin{array}{c}56,9 \pm \\
0,12 \\
\end{array}$ & 0,35 & $\begin{array}{c}54,3 \pm \\
0,40\end{array}$ & 1,29 & 53,17 & 50,62 & 55,71 & 5,09 \\
\hline Персея & $\begin{array}{l}35,6 \pm \\
0,43 \\
\end{array}$ & 2,11 & $\begin{array}{c}49,2 \pm \\
0,40 \\
\end{array}$ & 1,42 & $\begin{array}{c}45,2 \pm \\
0,52 \\
\end{array}$ & 1,99 & 43,33 & 39,30 & 47,37 & 8,07 \\
\hline Промінь & $\begin{array}{c}45,8 \pm \\
0,52 \\
\end{array}$ & 1,97 & $\begin{array}{c}59,1 \pm \\
0,52 \\
\end{array}$ & 1,52 & $\begin{array}{c}53,1 \pm \\
0,58 \\
\end{array}$ & 1,88 & 52,67 & 48,82 & 56,51 & 7,69 \\
\hline Саня & $\begin{array}{c}38,6 \pm \\
0,40 \\
\end{array}$ & 1,81 & $\begin{array}{c}60,3 \pm \\
0,23 \\
\end{array}$ & 0,66 & $\begin{array}{c}51,5 \pm \\
0,35 \\
\end{array}$ & 1,18 & 50,13 & 43,83 & 56,43 & 12,60 \\
\hline $\bar{x}, \mathbf{ц / \mathbf { r a }}$ & 42,08 & & 56,38 & & 51,03 & & 49,83 & & & \\
\hline \multicolumn{11}{|c|}{$\begin{array}{c}\text { Статистичні показники для чинника "рік досліджень": } \\
\qquad F_{\text {фактичне }}=1,06>F_{\text {критичне }}=4,06 / \text {-level }=0,41\end{array}$} \\
\hline \multirow{3}{*}{$H^{\prime \prime P}{ }_{05}$} & \multicolumn{3}{|c|}{ Вплив генотипу } & \multicolumn{3}{|c|}{0,46} & \multicolumn{4}{|c|}{ p-level $=9,15^{-20}$} \\
\hline & \multicolumn{3}{|c|}{ Вплив екоградієнту } & \multicolumn{3}{|c|}{0,40} & \multicolumn{4}{|c|}{ p-level $=1,46^{-24}$} \\
\hline & \multicolumn{3}{|c|}{$\begin{array}{c}\text { Взаємодія } \\
\text { рік+zенотип }\end{array}$} & \multicolumn{3}{|c|}{0,80} & \multicolumn{4}{|c|}{$p$-level $=1,34^{-11}$} \\
\hline
\end{tabular}

Примітка, тут і далі: $\bar{x}$ - середнє арифметичне; $S^{x}$ - середньоквадратичне відхилення; $R$ - розмах варіювання ознаки; $V$ - коефіцієнт варіації; тіп - мінімальне, тах максимальне значення ознаки по досліду; p-level - довірчий рівень

Сорт-стандарт Новокитаївська проявив значну адаптивність до умов вирощування, що підтверджується високим рівнем урожайності 53,2 ц/га. Середнє популяційне значення перевищували сорти Новокитаївська, Промінь, Саня на 0,3 - 3,3 ц/га. Сорт Персея поступався за урожайністю середньому популяційному значенню в досліді. Найбільш сприятливим для формування урожайності

\footnotetext{
${ }^{18}$ Державна служба статистики України. URL: http://www.ukrstat.gov.ua.
} 
традиційних сортів виявився 2018 вегетаційний рік. Найнижча урожайність була виявлена в 2017 році та становила 42,1 ц/га.

Необхідно відмітити той факт, що отримані результати коефіцієнту варіації $(0,66-2,11 \%)$ вказують на низьку мінливість аналізованої ознаки у всіх сортів. Розмах варіювання за урожайністю впродовж років досліджень становив 5,1-12,6 ц/га. Найменший його показник спостерігався в сорту Новокитаївська за урожайності 53,2 ц/га. Найбільший розмах варіювання досліджуваної ознаки спостерігали в сорту-стандарту Саня за урожайності 50,1 ц/га.

Аналіз статистичних показників вказує на істотний вплив різних факторів (генотипу, екоградієнту та взаємодію року+генотипу) на урожайність малини в умовах СНАУ. Дисперсійний аналіз урожайності осіннього періоду ремонтантних сортів за всіма роками свідчить про незначну $\left(\mathrm{p}<8,73^{-08}\right)$ між сортами.

Останнім часом створена нова серія ремонтантних сортів малини, адаптованих до умов північно-східного Лісостепу України. Багато з них характеризуються значним потенціалом продуктивності та володіють іншими господарсько-цінними ознаками. В наших дослідженнях, у літній період (табл. 2) сорти Бабине літо та Космічна за врожайністю проявили себе краще у 2019 році. Умови 2018 р. виявилися більш сприятливими для сортів Зєва, Бруквяна, порівняно з 2019 р. Літній період вегетації 2017 року виявився менш сприятливим для всіх досліджуваних зразків. Дисперсійний аналіз урожайності літнього періоду ремонтантних сортів за всіма роками свідчить про високу істотну різницю $\left(\mathrm{p}<6,24^{-04}\right)$ між сортами.

У досліджуваних генотипів у літній період за роками урожайність варіювала від 24,4 (сорт Зєва, 2017 р.) до 34,7 ц/га (Бабине літо-St, 2019 р.). Середнє популяційне значення ознаки складало 29,59 ц/га. Впродовж досліджень виділилися сорти, які перевищували середнє популяційне значення - Бабине літо (> на 2,51 ц/га), Бруквяна (> на 2,81 ц/га), останній сорт перевищував за врожайністю стандарт. Необхідно відмітити той факт, що отримані результати коефіцієнту варіації $(0,69-5,79 \%)$ вказують на низьку мінливість аналізованої ознаки у всіх сортів. Розмах варіювання за урожайністю впродовж років досліджень становив 1,3-3,4 ц/га. Найменший його показник спостерігався в сорту Зєва за урожайності 25,7 ц/га. Найбільший розмах варіювання досліджуваної ознаки спостерігали в сорту-стандарту Бабине літо за урожайності 32,1 ц/га.

В осінній період (табл. 3) кращими, порівняно з літнім періодом, виявилися всі ремонтантні сорти малини, лише сорт-стандарт поступався за врожайністю літнім показникам. Осінній період 2019 року виявився найбільш сприятливим для формування врожаю майже всіх досліджуваних сортів, окрім сорту Зєва, для якого пік урожайності виявлено в осінній період 2018 року. Дисперсійний аналіз урожайності осіннього періоду ремонтантних сортів за всіма роками свідчить про високу істотну різницю $\left(\mathrm{p}<8,73^{-08}\right)$ між сортами. 
Таблиця 2

Характеристика ремонтантних сортів малини за врожайністю у літній період, 2017-2019 рр.

\begin{tabular}{|c|c|c|c|c|c|c|c|c|c|c|}
\hline \multirow[b]{3}{*}{ Сорти } & \multicolumn{6}{|c|}{ Статистичні показники за роками } & \multicolumn{4}{|c|}{ За три роки, ц/га } \\
\hline & \multicolumn{2}{|c|}{2017 p. } & \multicolumn{2}{|c|}{2018 p. } & \multicolumn{2}{|c|}{2019 p. } & \multirow[b]{2}{*}{$\bar{x}$} & \multicolumn{2}{|c|}{$\begin{array}{l}\text { Область } \\
\text { похибки }\end{array}$} & \multirow[b]{2}{*}{$\mathrm{R}$} \\
\hline & $\begin{array}{c}\bar{x}_{ \pm} \\
\overline{\bar{x}} \\
\mathrm{~S}^{2}, \\
\text { ц/га }\end{array}$ & $\begin{array}{l}\mathrm{V}, \\
\%\end{array}$ & $\begin{array}{c}\bar{x}_{ \pm} \\
\overline{\mathrm{S}} \bar{x} \\
\text { ц/га }\end{array}$ & $\mathrm{V}, \%$ & $\begin{array}{c}\bar{x}_{ \pm} \\
\mathrm{S} \bar{x}, \\
\text { ц/га }\end{array}$ & $\begin{array}{l}\mathrm{V} \\
\%\end{array}$ & & $\min$ & $\max$ & \\
\hline $\begin{array}{c}\text { Бабине літо } \\
(\mathrm{St})\end{array}$ & $\begin{array}{c}28,9 \pm \\
0,12 \\
\end{array}$ & $\begin{array}{c}0,6 \\
9\end{array}$ & $\begin{array}{c}32,7 \pm \\
0,64\end{array}$ & 3,36 & $\begin{array}{c}34,7 \pm \\
0,69 \\
\end{array}$ & 3,46 & 32,1 & 30,40 & 33,80 & 3,40 \\
\hline Зєва & $\begin{array}{c}24,4 \pm \\
0,40\end{array}$ & $\begin{array}{c}2,8 \\
7\end{array}$ & $\begin{array}{c}26,4 \pm \\
0,98\end{array}$ & 6,44 & $\begin{array}{c}26,2 \pm \\
0,46\end{array}$ & 3,05 & 25,7 & 25,03 & 26,30 & 1,27 \\
\hline Космічна & $\begin{array}{c}26,3 \pm \\
0,17\end{array}$ & $\begin{array}{c}1,1 \\
4\end{array}$ & $\begin{array}{c}28,7 \pm \\
0,46\end{array}$ & 2,79 & $\begin{array}{c}29,6 \pm \\
0,40\end{array}$ & 2,36 & 28,2 & 27,22 & 29,18 & 1,97 \\
\hline Бруквяна & $\begin{array}{c}31,1 \pm \\
0,64\end{array}$ & $\begin{array}{c}3,5 \\
4\end{array}$ & $\begin{array}{c}33,4 \pm \\
0,98\end{array}$ & 5,09 & $\begin{array}{c}32,8 \pm \\
1,10\end{array}$ & 5,79 & 32,4 & 31,74 & 33,12 & 1,38 \\
\hline $\bar{x}$, ц/га & 27,67 & & 30,30 & & 30,82 & & 29,59 & & & \\
\hline \multicolumn{11}{|c|}{$\begin{array}{c}\text { Статистичні показники для чинника «рік досліджень»: } \\
F_{\text {фактичне }}=8,91>F_{\text {критичне }}=4,06 / \text { p-level }=6,24^{-04}\end{array}$} \\
\hline \multirow{3}{*}{$\mathrm{HIP}_{05}$} & \multicolumn{3}{|c|}{ Вилив генотипу } & \multicolumn{3}{|c|}{0,72} & \multicolumn{4}{|c|}{$p$-level $=3,31^{-12}$} \\
\hline & \multicolumn{3}{|c|}{ Вилив екоградієнту } & \multicolumn{3}{|c|}{0,62} & \multicolumn{4}{|c|}{ p-level $=9,16^{-07}$} \\
\hline & \multicolumn{3}{|c|}{$\begin{array}{c}\text { Взаємодія } \\
\text { рік+генотип }\end{array}$} & \multicolumn{3}{|c|}{1,24} & \multicolumn{4}{|c|}{$p$-level $=0,08$} \\
\hline
\end{tabular}

Таблиця 3

Характеристика ремонтантних сортів малини за врожайністю в осінній період, 2017-2019 рр.

\begin{tabular}{|c|c|c|c|c|c|c|c|c|c|c|}
\hline \multirow[b]{3}{*}{ Сорти } & \multicolumn{6}{|c|}{ Статистичні показники за роками } & \multicolumn{4}{|c|}{ За три роки, ц/га } \\
\hline & \multicolumn{2}{|c|}{2017 p. } & \multicolumn{2}{|c|}{2018 p. } & \multicolumn{2}{|c|}{2019 p. } & \multirow[b]{2}{*}{$\bar{x}$} & \multicolumn{2}{|c|}{$\begin{array}{l}\text { Область } \\
\text { похибки }\end{array}$} & \multirow[b]{2}{*}{$\mathrm{R}$} \\
\hline & $\begin{array}{c}\bar{x}_{ \pm \mathrm{S}} \\
\bar{x}, \\
\text { ц/га }\end{array}$ & $\mathrm{V}$ & $\begin{array}{c}\bar{x} \pm \\
-\bar{x} \\
\mathrm{~S}^{x}, \\
\text { ц/а }\end{array}$ & $\mathrm{V}, \%$ & $\begin{array}{c}\bar{x}_{ \pm} \\
\overline{\bar{x}} \\
\mathrm{~s}^{-} \\
\text {ц/га }\end{array}$ & $\begin{array}{l}\mathrm{V}, \\
\%\end{array}$ & & $\min$ & $\max$ & \\
\hline $\begin{array}{c}\text { Бабине літо } \\
\text { (St) }\end{array}$ & $\begin{array}{c}24,7 \pm \\
0,46\end{array}$ & 3,24 & $\begin{array}{c}25,1 \pm \\
0,52\end{array}$ & 3,59 & $\begin{array}{c}26,4 \pm \\
0,35\end{array}$ & 2,27 & 25,4 & 24,89 & 25,91 & 1,03 \\
\hline Зева & $\begin{array}{c}31,4 \pm \\
0,35\end{array}$ & 1,91 & $\begin{array}{c}33,5 \pm \\
0,35\end{array}$ & 1,79 & $\begin{array}{c}32,1 \pm \\
0,52 \\
\end{array}$ & 2,80 & 32,3 & 31,72 & 32,95 & 1,23 \\
\hline Космічна & $\begin{array}{c}43,2 \pm \\
1,04 \\
\end{array}$ & 4,17 & $\begin{array}{c}45,5 \pm \\
0,35 \\
\end{array}$ & 1,32 & $\begin{array}{c}47,1 \pm \\
0,52 \\
\end{array}$ & 1,91 & 45,3 & 44,13 & 46,40 & 2,26 \\
\hline Бруквяна & $\begin{array}{c}45,9 \pm \\
0,06 \\
\end{array}$ & 0,22 & $\begin{array}{c}46,7 \pm \\
0,46 \\
\end{array}$ & 1,71 & $\begin{array}{c}47,8 \pm \\
0,29 \\
\end{array}$ & 1,05 & 46,8 & 46,25 & 47,35 & 1,10 \\
\hline$x_{, ц / \mathbf{a}}$ & 36,30 & & 37,70 & & 38,35 & & $\mathbf{3 7 , 4 5}$ & & & \\
\hline \multicolumn{11}{|c|}{$\begin{array}{c}\text { Статистичні показники для чинника "рік досліджень»": } \\
F_{\text {фактичне }}=191,36>F_{\text {критичне }}=4,06 / \text { p-level }=8,73^{-08}\end{array}$} \\
\hline \multirow{3}{*}{$\mathbf{H I P}_{05}$} & \multicolumn{3}{|c|}{ Вплив генотипу } & \multicolumn{3}{|c|}{0,53} & \multicolumn{4}{|c|}{$p$-level $=8,28^{-27}$} \\
\hline & \multicolumn{3}{|c|}{ Вилив екоградієнту } & \multicolumn{3}{|c|}{0,46} & \multicolumn{4}{|c|}{ p-level $=1,50^{-05}$} \\
\hline & \multicolumn{3}{|c|}{$\begin{array}{c}\text { Взаємодія } \\
\text { рік+генотип }\end{array}$} & \multicolumn{3}{|c|}{0,92} & \multicolumn{4}{|c|}{$p$-level $=1,91^{-03}$} \\
\hline
\end{tabular}


В осінній період за роками урожайність варіювала від 24,7 (сорт Бабине літо-St, 2017 р.) до 47,8 ц/га (Бруквяна, 2019 р.). Середнє популяційне значення ознаки складало 37,45 ц/га. Упродовж років досліджень виділилися сорти, які перевищували середнє популяційне значення - Космічна (> на 7,85 ц/га), Бруквяна (> на 9,35 ц/га), проте сорт-стандарт перевищували усі досліджувані зразки. Необхідно відмітити той факт, що отримані результати коефіцієнту варіації $(0,22-$ $3,59 \%$ ) за врожайністю також вказують на низьку мінливість аналізованої ознаки у всіх сортів у осінній період. Розмах варіювання за урожайністю впродовж років досліджень становив 1,0-2,3 ц/га. Найменший його показник спостерігався в сорту Зєва за урожайності 32,3 ц/га. Найбільший розмах варіювання досліджуваної ознаки спостерігали в сорту-стандарту Космічна за урожайності 45,3 ц/га.

Згідно 3 відгуками дослідників ${ }^{19}, 20$, адаптивний потенціал ремонтантних сортів грунтується на підвищеній резистентності проти найбільш шкідливих захворювань, ймовірно, завдяки цьому вони характеризуються підвищеною урожайністю порівняно з традиційними сортами малини (табл.4). Загалом менше накопичення патогенів у насадженнях ремонтантних сортів імунна, на нашу думку, забезпечує більш високий рівень фізіологічної активності організму і спроможність протидіяти шкодочинним агентам, що своєю чергою дозволяє зменшити застосування хімічного методу захисту і підвищити рівень рентабельності вирощуваної культури.

Показники потенційної продуктивності зумовили певний господарський урожай. Найвищим він був у традиційних сортів Промінь та Новокитаївська $(52,7-53,2$ ц/га), а в ремонтантних Космічна та Бруквяна $(73,5-79,2$ ц/га). Останні формували істотно вищий врожай порівняно не тільки 3 контролем, а й 3 іншими досліджуваними сортами. Найнижча врожайність спостерігалась у сорту традиційного типу Персея, решту досліджуваних сортів віднесено до середньоврожайних (50-80 ц/га). Загалом випробовувані ремонтантні сорти відзначаються достатнім плодоношенням у перший рік садіння. Проте необхідно пам'ятати, що продуктивність рослин малини - це показник, який залежить від кількох компонентів: число плодоносних пагонів у кущі, кількість ягід на одному пагоні, середня маса ягоди. Крім того, продуктивність ремонтантної малини знаходиться в прямій залежності від кількості ягід, які встигли дозріти

${ }^{19}$ Снежко И.А. Ремонтантная малина в Ленинградской области. Продуктивность и качество ягод. Известия СПбГАУ, 2011. №. 23. С. 19-24.

${ }^{20}$ Щербакова Г.В., Снежко И.А. Агробиологические особенности ремонтантной малины в Ленинградской области. Известия 23 Международной академии аграрного образования. 2012. № 13. С. 22-25.

Снежко И.А. Биологические особенности малины ремонтантного типа в условиях Северо-Западного региона. Материаль Международного конгресса. СПб., $2010.91 \mathrm{c}$. 
до настання осінніх заморозків. Тому величина врожаю залежить не тільки від генотипу рослини, але і від погодних умов, періоду вегетації і його тривалості.

Таблиця 4

Порівняльна характеристика ремонтантних та традиційних сортів малини за врожайністю, середнє за роки досліджень

\begin{tabular}{|c|c|c|c|c|c|c|c|c|}
\hline & \multicolumn{4}{|c|}{ Традиційні сорти } & \multicolumn{4}{|c|}{ Ремонтантні сорти } \\
\hline & 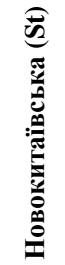 & 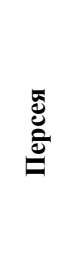 & 音 & Uू & 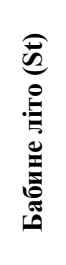 & 芯 & 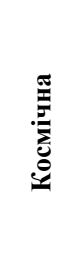 & 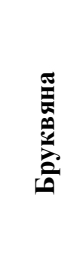 \\
\hline Урожайність, ц/га & 53,2 & 43,3 & 52,7 & 50,1 & 57,5 & 58,0 & 73,5 & 79,2 \\
\hline $\begin{array}{c}+/ \text { - до контролю, } \\
\text { ц/га }\end{array}$ & - & $-9,9$ & $-0,5$ & $-3,1$ & - & 0,5 & 16,0 & 21,7 \\
\hline \% до контролю & - & 81,5 & 99,1 & 94,3 & - & 100,9 & 127,8 & 137,7 \\
\hline $\begin{array}{c}\text { Середня } \\
\text { урожайність в групі, } \\
\text { ц/га }\end{array}$ & \multicolumn{4}{|c|}{49,8} & \multicolumn{4}{|c|}{67,1} \\
\hline
\end{tabular}

\section{ВИСНОВКИ}

1. Розширювати сортимент малини 3 метою закладання нових промислових насаджень у північно-східному Лісостепу України за рахунок високоадаптованих ремонтантних сортів малини Космічна та Бруквяна, що характеризуються високою i сталою врожайністю, а також які на основі досліджень внесено до «Реєстру сортів рослин, придатних для поширення в Україні».

2. Для отримання високих щорічних урожаїв ремонтантних сортів на рівні понад 70 ц/га та покращення санітарного стану ягідника сорти рекомендовано вирощувати малину за типом однорічної культури.

3. Встановлено, що за адаптивністю до грунтово-кліматичних умов північно-східного Лісостепу України найбільш продуктивними сортами серед традиційних сортів виявився сорт Промінь.

4. Серед ремонтантних сортів найбільш продуктивними виявилися сорти Космічна і Брусвяна, які мали істотно вищу врожайність за сортконтролю. 


\section{АНОТАЦІЯ}

Вивчали продуктивність різних сортів малини традиційних сортів, а також ремонтантних сортів малини селекції України в польових умовах Впродовж досліджень виділилися сорти, які перевищували середнє популяційне значення. Наведені результати порівняльної характеристики ремонтантних та традиційних сортів малини за врожайністю. Виділені найбільш продуктивні генотипи, перспективні для вирощування в умовах Північно-східного Лісостепу України, традиційні Промінь та Новокитаївська (52,7-53,2 ц/га), а серед ремонтантних - Космічна та Бруквяна (73,5-79,2 ц/га). Останні формували істотно вищий врожай порівняно не тільки з контролем, а й з іншими досліджуваними сортами.

\section{ЛІТЕРАТУРА}

1. Барабаш О.Ю., Леонтьєв О.М., Гонтар В.Т. Овочівництво і плодівництво : підручник. Київ : Вища школа, 2000. 503c.

2. Витковский Л.В. Плодовые растения мира. Санкт-Петербург : «Лань», 2003. С. 364-368.

3. Державна служба статистики України. URL: http://www.ukrstat.gov.ua.

4. Державний реєстр сортів рослин, придатних до поширення в Україні в 2019 році / Держ. ветер. та фітосанітарна служба України. Київ : Алефа, 2019. 497 с.

5. Жуковский П.М. Культурные растения и их сородичи. Ленинград, 1971. 752 с.

6. Ильина С. Двенадцать месяцев здоровья. Энциклопедия народной медицины, т. II. Київ : Логос, 1998. С. 31-33.

7. Касіянчук В.Д., Ковач М.М., Касіянчук М.В. Перспективи використання дикоростучих плодів, ягід і грибів в умовах Прикарпаття для виготовлення продукції лікувально-профілактичного призначення. Науковий вісник національного лісотехнічного університету Украӥни. 2013. Вип. 23.7. С. 152-155.

8. Марковський В.С., Бахмат M.I. Ягідні культури в Україні. Кам'янець-Подільський : ПП «Медозбори-2006», 2008. 200 с.

9. Ратомська 3.С. Механізація рільництва і садівництва : підручник. Київ : Видавництво «А.С.К.», 2006.

10. Рожко Н.Д. Ягоды и их лечебные свойства. Здоровье. 1966. C. $38-40$.

11. Седов Е. Н., Огольцова Т. П. Программа и методика сортоизучения плодовых, ягодных и орехоплодных культур. Орел: Издво Всероссийского научно-исследовательского института селекции плодовых культур, 1999. 608 с. 
12. Снежко И.А. Биологические особенности малины ремонтантного типа в условиях Северо-Западного региона. Материаль Международного конгресса. Санкт-Петербург, 2010. 91 с.

13. Снежко И.А. Ремонтантная малина в Ленинградской области. Продуктивность и качество ягод. Известия СПбГАУ, 2011. №. 23. C. 19-24.

14. Шестопаль О.М. Типові технологічні карти на створення насаджень горіхоплідних та ягідних культур. Київ, 2006. 90 с.

15. Щербакова Г.В., Снежко И.А. Агробиологические особенности ремонтантной малины в Ленинградской области. Известия 23 Международной академии аграрного образования. 2012. № 13. C. 22-25.

\section{Information about authors:}

Horbas S. M.,

Candidate of Agricultural Sciences, Head of the Research Laboratory of Horticulture and Viticulture of the Faculty of Agrotechnologies and Environmental Management Sumy National Agrarian University of Sumy 160, G. Kondratyiva Str., Sumy, 40021, Ukraine

Bakumenko O. M., Candidate of Agricultural Sciences, Associate Professor of the Department of Plant Protection of the Faculty of Agrotechnologies and Environmental Management Sumy National Agrarian University of Sumy 160, G. Kondratyiva Str., Sumy, 40021, Ukraine 